\title{
PENGARUH BUDAYA KERJA, PENGALAMAN DAN DISIPLIN TERHADAP KINERJA PEGAWAI KANTOR KECAMATAN PEUSANGAN KABUPATEN BIREUEN
}

\author{
Mursal Ridha $\left.{ }^{1 *}\right)$ \\ ${ }^{1}$ KIP Kabupaten Bireuen \\ *) email: psmm.uniki@gmail.com
}

DOI:

https://doi.org/10.55178/idm.v2i4.224

ABSTRAK

Article history

Received:

September 16, 2021

Revised:

September 19, 2021

Accepted:

September 22, 2021

Page:

$62-71$

Kata kunci: budaya kerja, pengalaman kerja, disiplin kerja, Kinerja.
Penelitian ini bertujuan untuk meneliti pengaruh budaya kerja, pengalaman kerja dan disiplin kerja terhadap kinerja pegawai Kantor Kecamatan Peusangan Kabupaten Bireuen. Jenis penelitian yang digunakan adalah penelitian kuantitatif dengan pendekatan deskriptif dan metode penetian yang akan digunakan dalam penelitian ini adalah metode asosiatif dengan pendekatan kuantitatif, menggunakan analisis jalur. Berdasarkan hasil penelitian dan pembahasan masalah yang diteliti, diperoleh bahwa : 1). Budaya kerja berpengaruh terhadap Kinerja pegawai, dengan besar pengaruhnya 16,35\%. 2). Terbukti pengalaman kerja berpengaruh terhadap terhadap Kinerja pegawai, dengan besar pengaruhnya 15,68\%.3). Terdapat pengaruh secara signifikan disiplin kerja terhadap Kinerja pegawai kantor kecamatan Peusangan Kabupaten Bireuen sebesar 12,06\%. 4). Dan berdasarkan Nilai koefisien determinasi sebesar 0,440 menjelaskan bahwa kontribusi faktor budaya kerja, pengalaman kerja dan disiplin kerja pegawai terhadap Kinerja pegawai kantor Kecamatan Peusangan Kabupaten Bireuen sebesar 44\%. Sementara sisanya (nilai residu) dari peran variabel yang tidak diteliti sebesar 60\%. Nilai residu atau factor lain ini seperti kompensasi, iklim organisasi, fasilitas kerja, Diklat, Kepemimpinan, dan lain-lain.

\section{Pendahuluan (Introduction)}

Untuk mencapai tingkat kesuksesan dalam pelakasaan tugas, seorang pegawai memerlukan kinerja yang baik. Hal ini sejalan dengan upaya Pemerintah Pusat yang mengeluarkan sejumlah kebijakan dalam meningkatkan kinerja pegawai. Salah satunya adalah mengenai pedoman pengembangan budaya kerja yang tertuang dalam Peraturan Menteri Pemberdayagunaan Aparatur Negara dan Reformasi Birokrasi Nomor 39 Tahun 2012. Peraturan ini bertujuan agar terjadi peningkatan kinerja pegawai negeri.

Berbicara mengenai organisasi pemerintahan tentu hal pertama yang akan terpikir oleh kita adalah mengenai budaya yang ada di dalamnya, baik itu dari cara bekerja, hubungan sesama pegawai atau dengan pemimpinnya, keramah tamahan pegawai, keterbukaan dengan hal-hal baru dan sebagainya. Budaya di dalam instansi merupakan cerminan nilai-nilai, norma-norma, perilaku dan sikap dari para anggotanya yang kemudian menjadi sebuah pondasi kuat yang menggambarkan bagaimana para pegawai dalam setiap aktivitas sehari-hari melaksanakan kewajibannya, kegiatan yang dilaksanakan oleh para pegawai menjadi budaya kerja. Sehingga dapat dikatakan bahwa budaya kerja merupakan suatu pemahaman, sikap, perilaku, pola pikir, adat istiadat yang dianut dan diterapkan oleh para pegawainya dalam melaksanakan pekerjaannya di dalam organisasi tempat ia bekerja.

Budaya kerja merupakan nilai-nilai dalam sebuah organisasi dimana nilai itu akan menentukan kualitas pekerjaan para pegawainya, apabila para pegawai dapat bekerja dengan menerapkan budaya kerja produktif atau budaya kerja positif maka dapat dipastikan para pegawai dapat meningkatkan kemampuan kualitas kerjanya dan pelayanan yang diberikan baik itu kepada instansi tempatnya bekerja atau juga kepada masyarakat. 
Budaya kerja merupakan hal yang sangat penting untuk diimplementasikan dalam kehidupan berorganisasi, khususnya organisasi pemerintah. Hal ini lebih difokuskan pada budaya kerja dari sumber daya manusia atau aparatur Negara dalam mengimplementasikan program-program pemerintah dan pembangunan. Penerapan budaya kerja diperlukan dikeranakan kondisi yang cukup memprihatinkan dikalangan aparatur Negara yang masih mengabaikan nilai-nilai moral dan budaya kerja dalam mengemban tugasnya.

Selain faktor budaya kerja, pengalaman kerja pegawai juga sangat penting dalam menjalankan Pemerintahan. Pada dasarnya setiap instansi yang telah didirikan selalu mempunyai harapan bahwa di kemudian hari akan mengalami perkembangan yang baik di dalam lingkup instansi tersebut dan menginginkan terciptanya kinerja yang efektif dalam bidang pekerjaannya. Karena dalam keberadaan suatu intansi yang berbentuk apapun baik dalam skala besar maupun kecil dibutuhkan sumber daya manusia untuk mengatur dan mengatasi masalah-masalah yang berhubungan dengan kinerja pegawai, baik dalam hal pembagian tugas maupun kegiatan sumber daya manusia.

Pengalaman kerja mempunyai pengaruh terhadap banyaknya produksi, besar kecilnya dan efisiensi yang dapat dilihat dari hasil produksi tenaga kerja yang diarahkan. Dalam pengertian lain, pengalaman kerja juga dapat diperoleh dengan melewati masa kerja yang telah dilakui disuatu tempat kerja. Pengalaman kerja seseorang dalam suatu pekerjaan yang dimanifestasikan dalam jumlah masa kerja akan meningkatkan kemampuan dan kecakapan kerja seseorang sehingga hasil kerja akan semakin meningkat.

Pengalaman kerja tidak hanya menyangkut jumlah masa kerja, tetapi lebih dari juga memperhitungkan jenis pekerjaan yang pernah atau sering dihadapi. Sejalan dengan bertambahnya pekerjaan, maka akan semakin bertambah pula pengatahuan dan ketrampilan seseorang dalam bekerja. Hal tersebut dapat dipahami karena terlatih dan sering mengulang suatu pekerjaan sehingga kecakapan dan ketrampilan semakin dikuasai secara mudah.

Selain itu disiplin kerja juga sangat berhubungan dengan kinerja pegawai. Menurut Indah Puji Hartatik (2014:182) disiplin merupakan suatu keadaan tertentu dimana orang-orang yang tergabung dalam organisasi tunduk pada peraturan-peraturan yang ada dengan rasa senang hati. Sedangkan kerja adalah segala aktivitas manusia yang dilakukan untuk mencapai tujuan yang telah ditetapkan. Disiplin termasuk dalam sikap mental pegawai. Yang dimaksud dalam sikap mental adalah sikap terhadap kerja itu sendiri, terhadap bekerja dalam industir, terhadap perlunya menghasilkan produk bermutu, terhadap pelayanan prima kepada pelanggan, dan akhirnya terhadap integrasi moral serta reputasi. Kedisiplinan harus ditegakan dalam suatu organisasi, karena tanpa dukungan disiplin personel yang baik, organisasi akan sulit mewujudkan tujuannya. Jadi, dapatlah dikatakan bahwa kedisiplinan merupakan kunci keberhasilan suatu organisasi dalam mencapai tujuan yang telah ditentukan.

Masih rendahnya sebagian pegawai di lingkungan kantor Kecamatan Peusangan Kabupaten Bireuen. Hal ini ditandai dengan kontribusi pegawai dalam mengelola daerah umumnya dan pelayanan terhadap masyarakat di wilayah Peusangan, dirasakan oleh sebagian masyarakat belum optimal. Maka berdasarkan latar belakang masalah inilah maka peneliti tertarik untuk meneliti pengaruh pengalaman mengajar, motivasi kerja dan kompetensi guru terhadap kinerja guru. sehingga penulis perlu mengangkat penelitian yang berjudul "Pengaruh Budaya Kerja, Pengalaman dan Disiplin terhadap Kinerja Pegawai Kantor Kecamatan Peusangan Kabupaten Bireuen".

\section{Tinjauan Literatur (Literature Review)}

\section{Pengaruh Budaya Kerja terhadap Kinerja Pegawai}

Secara impilist adanya korelasi antara kekuatan pendorong kerja dan perilaku menghasilkan manusia bekerja efektif dan efisien. Setiap orang dalam organisasi selayaknya memahami bahwa bekerja bukan semata-mata untuk memenuhi kebutuhan dasar, lebih dari itu yakni kesadaran bekerja dengan etos memenuhi prinsip etika dan semangat kerja tinggi untuk mencapai tujuan organisasi (Sedarmayanti, 2014:77). Menurut Moeheriono (2012:346) budaya kerja adalah cara pandang serta suasana hati yang menumbuhkan keyakinan yang kuat atas dasar nilai- nilai yang diyakininya serta memiliki semangat yang tinggi dan sungguh- sungguh untuk mewujudkan prestasi kerja terbaik.

Harus disadari pula bahwa budaya erat kaitannya dengan manusia. Kuatnya budaya kerja akan terlihat dari bagaimana karyawan memandang budaya kerja sehingga berpengaruh terhadap kinerja kerjanya yang digambarkan memiliki motivasi, dedikasi, kreativitas, kemampuan dan komitmen yang tinggi. Semakin kuat budaya kerja, semakin tinggi komitmen dan kemampuan yang dirasakan karyawan. Makin banyak karyawan yang menerima nilai-nilai makin tinggi kemampuan dan komitmen mereka pada nilai-nilai itu makin kuat budaya tersebut Menurut Wolsely dan Campbell (Prasetya, 2001:12) orang yang terlatih dalam 
budaya kerja akan menyukai kebebasan, pertukaran pendapat, terbuka bagi gagasan baru dan fakta baru, memecahkan permasalahan secara mandiri, berusaha menyesuaikan diri antara kehidupan pribadi dan sosialnya.

Hal ini dibuktikan juga dalam penelitian Asyrori (2014) di kantor Kecamatan Sambutan Kota Samarinda. Hasil penelitian dapat disimpulkan bahwa terdapat Hubungan antara Budaya Kerja dengan Kinerja Pegawai di Kantor Kecamatan tersebut.

\section{Pengaruh Pengalaman Kerja terhadap Kinerja Pegawai}

Pengalaman kerja sangat berperan dalam meningkatkan kinerja pegawai Pegawai akan lebih mudah dan cepat dalam melaksanakan pekerjaan atau tugasnya, karena mempunyai pengalaman yang lebih dalam pekerjaannya. Sehingga ini akan meningkatkan kinerja nya dan juga meningkatkan kinerja organisasi. Adanya pengaruh pengalaman kerja terhadap kinerja pegawai di dukung oleh pendapat dari Robbins dan Timothy (2008) menyatakan bahwa pengalaman kerja adalah tingkat penguasaan pengetahuan dan keterampilan seseorang dalam bekerja yang tampaknya menjadi sebuah dasar perkiraan yang baik atas kinerja pegawai.

Hal ini juga dibuktikan dari penelitian Wanceslaus Bili, dkk (2018) di Kantor Kecamatan Laham Kabupaten Mahakam Ulu. Dengan simpulan bahwa pengalaman kerja mempunyai pengaruh yang signifikan terhadap kinerja pegawai di Kantor Kecamatan tersebut.

\section{Pengaruh Disiplin Kerja terhadap Kinerja Pegawai}

Disiplin yang baik mencerminkan besarnya tanggung jawab seseorang terhadap tugas-tugas yang diberikan kepadanya. Seseorang dikatakan mempunyai disiplin kerja yang tinggi jika yang bersangkutan konsekuen, konsisten, taat asas, bertanggung jawab atas tugas yang diamanahkan kepadanya. Disiplin kerja merupakan suatu alat yang digunakan para manajer untuk berkornunikasi dengan karyawan agar mereka bersedia untuk mengubah prilaku serta sebagai suatu upaya untuk meningkatkan kesadaran dan kesediaan seseorang mentaati semua peraturan perusahaan dan norma-norma sosial yang berlaku. Dengan disiplin kerja yang tinggi akan dapat membantu meningkatkan kinerja.

Hal tersebut dikarenakan disiplin kerja dan kinerja mempunyai keterhubungan, sesuai dengan penjelasan Leiden (2001:63) mengemukakan bahwa dengan ditegakannya disiplin maka dapat mengatasi masalah kinerja yang buruk dan memperkuat pengaruh prilaku kerja pegawai dalam kelompok atau organisasi. Apabila disiplin dapat dilaksanakan dengan baik serta tidak menunda waktu maka masalah kinerja tidak dibiarkan menjadi parah, dan kemungkinan masalah yang terjadi dapat diatasi secara tepat dan mudah.

Hal ini dibuktikan dari penelitian Sutarno (2016) di Kecamatan Pataruman Kota Banjar. Menghasilkan bahwa disiplin kerja telah berpengaruh signifikan terhadap kinerja Pegawai, dan merekomendasikan bahwa faktor disiplin kerja hal yang sangat penting untuk meningkatkan kinerja pegawai dalam memecahkan berbagai masalah yang dihadapai pada masyarakat di Kecamatan tersebut.

\section{Metode Penelitian (Methodology)}

\section{a. Metode dan Variabel Penelitian}

Penelitian ini dilaksanakan pada Kantor Kecamatan Peusangan Kabupaten Bireuen. pada bulan Maret 2021. Dengan mengambil objek pegawai sejumlah 66 pegawai aktif sebagai PNS, dengan pendekatan metode asosiatif secara kuantitatif, sehingga dapat mengungkap pengaruh faktor yang diduga memberi kontribusi nyata terhadap kinerja pegawai. Adapun variabel, dimensi dan indikator pengukur setiap variabelnya dinyatakan berikut ini.

Tabel 1. Operasional Variabel Penelitian

\begin{tabular}{|l|l|}
\hline \multicolumn{1}{|c|}{ Variabel } & \multicolumn{1}{c|}{ Dimensi/Indikator } \\
\hline $\begin{array}{l}\text { Budaya Kerja }\left(\mathrm{X}_{1}\right) \\
\text { Sumber: }\end{array}$ & - Profesionalisme \\
Mangkunegara $(2005: 113)$ & - Disiplin \\
& - Kerjasama \\
\hline Pengalaman kerja $\left(\mathrm{X}_{2}\right)$ & - Kejujuran \\
Sumber: & - Tingkat pengetahuan dan keterampilan yang dimiliki \\
Marihot $(2013)$ & - Penguasaan terhadap pekerjaan dan peralata \\
\hline
\end{tabular}




\begin{tabular}{|l|l|}
\hline Disiplin kerja $\left(\mathrm{X}_{3}\right)$ & - Aturan Waktu \\
Sumber: Hasibuan (2012) & - Taat terhadap peraturan \\
\hline Kinerja (Y) & - Pturan nerilakudalam nekeriaan \\
Sumber: Peraturan Pemerintah Kerja \\
RI No 46 Tahun 2011 & - Sasaran Kinerja Pegawai (SKP) \\
\hline
\end{tabular}

\section{b. Teknik Pengumpulan Data}

Untuk mendapatkan data sebagai dasar analissis masalah, menggunakan teknik atau cara dengan 1). Observasi, yang berkaiatan fenomena yang terjadi di wilayah penelitian, dan 2). Melalui angket atau kuesioner yang disebarkan terhadap responden dalam memperoleh data dan skor penilaian variabel yang diteliti.

\section{c. Alat Analisis}

Berkaitan dengan metode penelitian dengan asosiatif secara kuantititatif, dan antar variabel bebas memiliki hubungan kausalitas, maka alat analisis yang dipakai dengan statistik parametrik, yakni model dengan Analisis jalur yang merupakan bagian dari analisis regresi berganda.

Sebagai mana rumusan masalah penelitian yang terdiriatas variabel eksogen $\left(\mathrm{X}_{1}, \mathrm{X}_{2}, \mathrm{X}_{3}\right)$ yang di duga berpengaruh terhadap variabel endogen (terikat: Y). Maka akan dilakukan perhitungan statisti dengan model jalur yang dapat mengungkap besaran pengaruh kausal langsung, kausal tidak langsung, kausal total maupun simultan seperangkat variabel eksogen tersebut.

Terdapat beberapa prinsip dasar (asumsi) yang mendasari analisis jalur, diantaranya a) hubungan antar variabel adalah bersifat linier, adaptif, dan bersifat normal, b) Data dari Variabel, minimal dalam skala ukur interval dan ratio, c) Jika objek berupa sampel, maka menggunakan sampel probability sampling, d) Variabel observasi diukur tanpa kesalahan (instrumen pengukuran valid dan reliabel), artinya variabel yang diteliti dapat diobservasi secara langsung. Dan model yang dianalisis dispesifikasikan (diidentifikasi) dengan benar Untuk dapat menggunakan alat analisis ini, juga menuntut jaminan atau syarat statistik parametrik yakni terpenuhinya semua asumsi klasik, yaitu asumsi normalitas, heterosidasitas, multikolinieritas dan autokorelasi.

\section{Hasil dan Pembahasan (Results and Discussion)}

\section{a. Karakteristik Responden Penelitian}

Karakteristik responden menggambarkan kondisi fisik atau ciri demografis dari pegawai menyangkut jenis kelamin, umur, pendidikan dan masa kerka, yakni dicantumkan dalam tabel berikut :

Tabel 2. Diskripsi Responden (Pegawai Kecamatan Peusangan, Bireuen)

\begin{tabular}{|l|l|c|c|}
\hline \multicolumn{2}{|c|}{ Keterangan } & Jumlah & Persentase (\%) \\
\hline \multirow{4}{*}{ Umur } & $\leq 40$ tahun & 21 & 31.82 \\
\cline { 2 - 4 } & $41-50$ tahun & 41 & 62.12 \\
\cline { 2 - 4 } & $>50$ tahun & 4 & 6.06 \\
\hline \multirow{4}{*}{ Penis Kelamin } & Laki - Laki & 54 & 81.82 \\
\cline { 2 - 4 } & Perempuan & 12 & 18.18 \\
\hline \multirow{4}{*}{ Lama kerja } & SMA/SMK & 54 & 81.82 \\
\cline { 2 - 4 } & D3 & 1 & 1.52 \\
\cline { 2 - 4 } & S1 & 11 & 16.67 \\
\cline { 2 - 4 } & S2 & 0 & 0.00 \\
\hline & $\leq 15 \mathrm{Th}$ & 7 & 10.61 \\
\cline { 2 - 4 } & $16-20 \mathrm{Th}$ & 35 & 53.03 \\
\cline { 2 - 4 } & $>20 \mathrm{Th}$ & $\mathbf{6 6}$ & 36.36 \\
\hline \multicolumn{2}{|c|}{ Jumlah Responden } & & $\mathbf{1 0 0}$ \\
\hline
\end{tabular}

Sumber : Data Primer yang diolah, 2021

\section{b. Uji Validitas Instrimen setiap Variabel}

Karena penelitian ini merupakan penelitian survei, pengumpulan data tentang variabel penelitian menggunakan angket atau kuesioner. Intrumen dalam angket dimunculkan atas dasar dimensi dan indikator 
variabel yang secara substansi atau teoritis dapat dan sesuai dengan konsep variabel yang digunakan. Namun untuk lebih meyakinkan bahwa butir-butir pernyataan dalam angket tentang indiator variabel tersebut terukur, akurat dan dapat dihandalkan, maka perlu dilakukan pengecekan. Dalam hal ini adalah pengujian secara statistik non parametrik, yakni uji validitas dan reliabilitas instrumen. Karena benar tidaknya data, tergantung dari baik tidaknya instrumen pengumpulan data.

\section{Uji Validitas Instrumen Budaya Kerja}

Sesuai dengan konsep operasional penelitian ini, variabel budaya kerja diukur melalui 4 dimensi (tabel 1). Dikembangkan dalam 8 (delapan) pernyataan yang diberikan kepada responden, dengan hasil uji validiasnya adalah:

Tabel 3. Uji Validitas Instrumen Pengukur Budaya Kerja

\begin{tabular}{|c|l|c|c|c|c|}
\hline No & \multicolumn{1}{|c|}{ Pernyataan } & r-hitung & r-min & r-tabel & Keputusan \\
\hline 1 & Hadir kerja tepat pada waktu & 0.787 & 0,300 & 0,244 & Valid \\
\hline 2 & Memakai seragam kerja & 0.726 & 0,300 & 0,244 & Valid \\
\hline 3 & $\begin{array}{l}\text { Menyelesaikan pekerjaan sesuai dengan yang } \\
\text { diperintahkan }\end{array}$ & 0.747 & 0,300 & 0,244 & Valid \\
\hline 4 & $\begin{array}{l}\text { Menanggung resiko bila pekerjaannya tidak } \\
\text { memuaskan. }\end{array}$ & 0.829 & 0,300 & 0,244 & Valid \\
\hline 5 & $\begin{array}{l}\text { Pemimpin memberikan kebebasan dalam memberikan } \\
\text { ide untuk kemajuan organisasi }\end{array}$ & 0.791 & 0,300 & 0,244 & Valid \\
\hline 6 & $\begin{array}{l}\text { Pimpinan memberikan kebebasan cara menyelesaikan } \\
\text { pekerjaan }\end{array}$ & 0.760 & 0,300 & 0,244 & Valid \\
\hline 7 & $\begin{array}{l}\text { Instansi memberikan kesempatan untuk mengem- } \\
\text { bangkan diri melalui program pelatihan dan } \\
\text { pengembangan pegawai }\end{array}$ & 0.748 & 0,300 & 0,244 & Valid \\
\hline 8 & $\begin{array}{l}\text { Instansi membebaskan pegawai untuk mengembangkan } \\
\text { diri lewat belajar sendiri/membentuk kelompok (tim) } \\
\text { dalam penyelesaian suatu permasalahan }\end{array}$ & 0.766 & 0,300 & 0,244 & Valid \\
\hline
\end{tabular}

Sumber: Data penelitian, hasil Olahan Data (2021)

Dari hasil perhitungan validitas variabel kompetensi, hasil r-hitung dibandingankan dengan r-min=0,300, dan juga terhadap r-tabel pada taraf uji 5\%, maka semuanya dinyatakan Valid untuk digunakan dalam penelitian ini. Karena r-hitung > 0,003, dan atau r-hitung >r-tabel.

\section{Uji Validitas Instrumen Pengalaman Kerja}

Instrumen yang mengukur variabel Pengalaman kerja menggunakan 3 (tiga) dimensi (Tabel 1). Yang dikembangkan dalam 10 (sepuluh) pernyataan, dengan hasil uji validitasnya adalah:

Tabel 4. Uji Validitas Instrumen Pengalaman Kerja

\begin{tabular}{|c|l|c|c|c|c|}
\hline No & \multicolumn{1}{|c|}{ Pernyataan } & r-hitung & r-min & r-tabel & Keputusan \\
\hline 1 & $\begin{array}{l}\text { Lama waktu bekerja dikantor ini memudahkan saya } \\
\text { dalam bekerja }\end{array}$ & 0.777 & 0,300 & 0,244 & Valid \\
\hline 2 & $\begin{array}{l}\text { Memiliki pengetahuan dan ketrampilan tentang } \\
\text { pekerjaan yang diberikan oleh pimpinan }\end{array}$ & 0.716 & 0,300 & 0,244 & Valid \\
\hline 3 & $\begin{array}{l}\text { Menguasai pekerjaan dan peralatan kerja yang } \\
\text { disediakan oleh instansi }\end{array}$ & 0.720 & 0,300 & 0,244 & Valid \\
\hline 4 & $\begin{array}{l}\text { Pengalaman kerja yang dimiliki membantu saya } \\
\text { dalam bekerja }\end{array}$ & 0.651 & 0,300 & 0,244 & Valid \\
\hline 5 & Bekerja sesuai dengan prosedur kerja yang berlaku & 0.868 & 0,300 & 0,244 & Valid \\
\hline 6 & $\begin{array}{l}\text { Ketrampilan yang dmiiliki diatas rata-rata dari } \\
\text { pegawai yang lain. }\end{array}$ & 0.634 & 0,300 & 0,244 & Valid \\
\hline 7 & Selama bekerja hampir tidak melakukan kesalahan & 0.766 & 0,300 & 0,244 & Valid \\
\hline 8 & Mnyelesaikan pekerjaan dengan tepat waktu & 0.207 & 0,300 & 0,244 & Tidak Valid \\
\hline 9 & Menguasai pekerjaan yang diberikan & 0.783 & 0,300 & 0,244 & Valid \\
\hline 10 & Hasil pekerjaan memuaskan pimpinan & 0.752 & 0,300 & 0,244 & Valid \\
\hline
\end{tabular}

Sumber: Data penelitian, hasil Olahan Data (2021)

Dari hasil perhitungan validitas variabel pengalaman kerja hasil r-hitung dibandingkan dengan r-min = 0,300, maupun dengan r-tabel pada taraf uji 5\%, maka terdapat 1 butir pernyataan dinyatakan tidak valid yakni butir nomor-8, sehingga hanya 9 butir dapat digunakan dalam penelitian ini. . 


\section{Uji Validitas Instrumen Disiplin Kerja}

Untuk mengukur Validasi item angket variabel disiplin kerja digunakan 3 (tiga) indikator, dan dikembangkan dalam 10 (sepuluh) pernyataan, dengan hasil uji validitasnya sebagai berikut:

Tabel 5. Uji Validitas Instrumen Disiplin kerja

\begin{tabular}{|c|c|c|c|c|c|}
\hline No & Pernyataan & r-hitung & r-min & r-tabel & Keputusan \\
\hline 1 & Memenuhi kehadiran kerja dengan baik & 0.741 & 0,300 & 0,244 & Valid \\
\hline 2 & Datang ke tempat kerja tepat waktu & 0.769 & 0,300 & 0,244 & Valid \\
\hline 3 & Selalu berhati-hati agar tidak terjadi kesalahan kerja & 0.730 & 0,300 & 0,244 & Valid \\
\hline 4 & $\begin{array}{l}\text { Tujuan dari pekerjaan yang dibebankan kepada pegawai } \\
\text { harus sesuai dengan kemampuan pegawai yang } \\
\text { bersangkutan }\end{array}$ & 0.685 & 0,300 & 0,244 & Valid \\
\hline 5 & $\begin{array}{l}\text { Pimpinan dapat dijadikan teladan dan panutan oleh para } \\
\text { bawahannya. }\end{array}$ & 0.726 & 0,300 & 0,244 & Valid \\
\hline 6 & $\begin{array}{l}\text { Balas jasa yang diterima dapat mempengaruhi } \\
\text { kedisiplinan pegawai. }\end{array}$ & 0.612 & 0,300 & 0,244 & Valid \\
\hline 7 & Keadilan pimpinan sudah diterapkan dengan baik & 0.831 & 0,300 & 0,244 & Valid \\
\hline 8 & $\begin{array}{l}\text { Adanya kebersamaan yang aktif antara atasan dan } \\
\text { bawahan, dapat membuat rasa harmonis dalam } \\
\text { mewujudkan kerjasama }\end{array}$ & 0.812 & 0,300 & 0,244 & Valid \\
\hline 9 & $\begin{array}{l}\text { Sanksi hukuman yang diterapkan ikut mempengaruhi } \\
\text { baik/buruknya kedisiplinan }\end{array}$ & 0.789 & 0,300 & 0,244 & Valid \\
\hline 10 & $\begin{array}{l}\text { Pimpinan yang berani bertindak tegas menerapkan } \\
\text { hukuman akan diakui kepemimpinannya oleh bawahan }\end{array}$ & 0.718 & 0,300 & 0,244 & Valid \\
\hline
\end{tabular}

Sumber: Hasil Olahan Data(2021)

Dari hasil perhitungan validitas variabel disiplin kerja $\left(\mathrm{X}_{3}\right)$, hasil $\mathrm{r}$-hitung dibandingkan dengan $\mathrm{r}-\mathrm{min}=$ 0,300 , maupun dengan r-tabel pada taraf uji 5\%, maka tampak hasilnya semua butir atau item pernyataan variabel ini dinyatakan valid, sehingga dapat digunakan untuk mengukur variabel disiplin kerja dalam penelitian ini.

\section{Uji Validitas Intrumen Kinerja}

Untuk variabel kinerja tidak dilakukan uji validitas, karena data yang digunakan adalah data sekunder hasil perhitungan sasaran kinerja pegawai di kantor Dinas pendidikan, tahun 2020. Dengan kisaran data SKP pegawai kantor kecamatan Peusangan Kabupaten Bireuen, adalah berikut ini;

Tabel 6. Sebaran Data SKP sebagai ukuran Kinerja (Y)

\begin{tabular}{|c|c|c|c|c|}
\hline No & Nilai SKP & Kategori & Jumlah & Persentase \\
\hline 1 & $\geq 85,00$ & Amat Baik & 5 & $7,58 \%$ \\
\hline 2 & $80-84$ & Baik & 44 & $66,67 \%$ \\
\hline 3 & $<80$ & Cukup Baik & 17 & $25,76 \%$ \\
\hline
\end{tabular}

Sumber: Hasil Olahan Data(2021)

Dari hasil perhitungan tabel diatas, maka secara rata-rata kinerja pegawai mencapai 81,48 termasuk baik. Terdapat 7,59\% yang dinyatakan amat baik, 66,67\% termasuk kategori baik dan 25,76\% masuk kategori cukup.

\section{Uji Reliabilitas Instrumen Penelitian}

Sedangkan untuk pengujian realibilitas instrument dihitung dengan menggunakan rumus koefisien Cronbach Alpha $(\alpha)$, dimana secara umum dianggap reliabel apabila nilai $\alpha>0,65$, jika Nilai koefisien reliabilitas yang baik adalah diatas 0,7 (cukup baik), di atas 0,8 (baik). (Sudjana, 2005:369.). Untuk mendapatkan nilai tingkat reliabilitas dimensi pembentuk variabel laten, digunakan rumus:

$$
r=\left[\frac{k}{(k-1)}\right]\left[1-\frac{\sum \sigma_{b}^{2}}{\sigma_{t}^{2}}\right] \ldots \text { (Riduwan, 2010:99). }
$$

Keterangan :

$\mathrm{r}=$ Koefisien relabilitas instrumen (cronbach alpha)

$\mathrm{k}=$ Banyaknya butir pernyatanaan atau banyaknya soal

$\Sigma \sigma_{\mathrm{b}}^{2}=$ Total varians butir

$\sigma_{\mathrm{t}}^{2}=$ Total varians 
Hasil uji reliabilitas semua variabel ditunjukkan pada lampiran 3 dengan hasil dalam tabel berikut:

Tabel 7. Hasil Uji Reliabilitas Instrumen Variabel

\begin{tabular}{|l|c|c|c|}
\hline \multicolumn{1}{|c|}{ Variabel } & Cronbach's Alpha & N of Items & Keterangan \\
\hline - Budaya kerja & 0,894 & 8 & Reliable \\
\hline - Pengalamaman kerja & 0,864 & 9 & Reliable \\
\hline - Disiplin kerja & 0,909 & 10 & Reliable \\
\hline - Kinerja & 0,894 & 8 & Reliable \\
\hline
\end{tabular}

Sumber: Hasil Olahan Data(2021)

Berdasarkan output yang diperoleh dari tabel di atas, diperoleh nilai koefisien reliabilitas pada semua variabel adalah realiable, dan hasilnya tinggi, karena koefisien reliabilitas pada variabel lebih besar dari 0,6, maka variabel-variabel yang digunakan pada instrumen tersebut adalah reliabel untuk digunakan dalam penelitian.

\section{c. Hasil analisis Deskriptif}

Hasil survey menggunakan angket dari variabel penelitian diperoleh informasi sebagai berikut.

Tabel 8. Deskripsi Pegawai tentang Variabel

\begin{tabular}{|c|c|c|c|c|c|c|}
\hline \multirow{2}{*}{ Variabel } & \multicolumn{5}{|c|}{ Persentase Jawaban setiap item (Jumlah) } & \multirow{2}{*}{$\begin{array}{c}\text { Skor } \\
\text { Pencapaian }\end{array}$} \\
\hline & STS & TS & KS & $\mathbf{S}$ & SS & \\
\hline \multirow{2}{*}{ - Budaya kerja } & 1 & 15 & 172 & 208 & 132 & \multirow{2}{*}{$\mathbf{7 7 , 2 3 \%}$} \\
\hline & 0.19 & 2.84 & 32.58 & 39.39 & 25.00 & \\
\hline \multirow{2}{*}{ - $\quad$ Pengalaman kerja } & 1 & 48 & 315 & 199 & 97 & \multirow{2}{*}{$\mathbf{7 0 , 3 9 \%}$} \\
\hline & 0.15 & 7.27 & 47.73 & 30.15 & 14.70 & \\
\hline \multirow{2}{*}{ - Disiplin kerja } & 3 & 25 & 254 & 217 & 161 & \multirow{2}{*}{$75,39 \%$} \\
\hline & 0.45 & 3.79 & 38.48 & 32.88 & 24.39 & \\
\hline
\end{tabular}

Sumber : Hasil Peneltian, 2021 (data diolah)

Berdasarkan tabel di atas dapat dijelaskan bahwa :

1. Variabel Budaya kerja yang terjadi pada kantor Kecamatan Peusangan Kabupaten Bireuen, baik dari aspek profesionalisme, disiplin, kerjasama, dan kejujuran. Menurut olahan data diatas, baru mencapai $77,23 \%$, belum optimal. Terdapat paling banyak yang menjawab setuju (39,39\%) dan kurang setuju $(32,58 \%)$ bahwa budaya kerja mendukung kinerja pegawai.

2. Variabel pengalaman kerja pegawai di kantor Kecamatan Peusangan Kabupaten Bireuen baru mencapai 70,39\%, belum maksimal. Hal ini dinilai dari aspek pengalaman dalam menyelesaikan pekerjaan, sikap profesional, melaksanakan tugas sesuai prosedur, meminimalkan kesalahan yang terjadi dalam pekerjaan. Menurut responden, paling banyak menjawab kurang setuju $(47,73 \%)$ dan setuju $(30,15 \%)$ bahwa pengalaman kerja pegawai dapat mendukung peningkatan kinerja yang baik.

3. Variabel disiplin kerja pegawai, berkaitan dengan kehadiran bekerja, mampu melaksanakan beban kerja dan kerjasama, dan perinsip penegakan disiplin kantor. Menurut persepsi responden paling banyak menjawab kurang setuju $(38,48 \%)$ dan setuju $(32,88 \%)$. Secara total pencapaian aspek disiplin kerja kurang optimal, baru mencapai $75,39 \%$.

\section{d. Hasil Analisis Jalur}

Untuk mengawali analisis jalur, dilakukan taksiran nilai koefisien jalur (Tabel 9) dan koefisien korelasi antar variabel eksogen (Tabel 10). Tabel berikut merupakan ditaksir nilai koefisien jalur antar variabel eksogen $\left(\mathrm{X}_{1}, \mathrm{X}_{2}, \mathrm{X}_{3}\right)$ terhadap variabel endogen $(\mathrm{Y})$, dengan hasilnya sebagai berikut:

Tabel 9. Taksiran Koefisien Jalur (p)

\begin{tabular}{|l|c|r|r|}
\hline \multirow{2}{*}{ Model } & Standardized Coefficients & & \multicolumn{1}{c|}{ Sig. } \\
\cline { 2 - 3 } & Beta & \multicolumn{1}{c|}{$\mathrm{t}$} & \multicolumn{1}{c|}{. } \\
\hline (Constant) & & 2.305 & .025 \\
\hline Budaya kerja & 0.288 & 2.014 & .048 \\
\hline Pengalaman kerja & 0.269 & 2.011 & .042 \\
\hline Disiplin kerja & 0.232 & &
\end{tabular}

a. Dependent Variable: Kinerja 
Berdasarkan tabel 9, melalui uji-t (kolom-3) tampak bahwa semua koefsien jalur dinyatakan signifikans pada taraf uji $5 \%$.

Pertama dilakukan taksiran nilai kausalitas antar variabel eksogen $\left(\mathrm{X}_{1}, \mathrm{X}_{2}, \mathrm{X}_{3}\right)$ yang hasilnya disajikan dalam lampiran-7A, yakni :

Tabel 10. Hubungan Kausal Antar Variabel Bebas (Eksogenus)

\begin{tabular}{|c|c|c|c|c|}
\hline & & Budaya kerja & Pengalaman kerja & Disiplin kerja \\
\hline \multirow[t]{3}{*}{ Budaya kerja } & Pearson Correlation & 1 & $.634^{* *}$ & $.471^{* * *}$ \\
\hline & Sig. (2-tailed) & & .000 & .000 \\
\hline & $\mathrm{N}$ & 66 & 66 & 66 \\
\hline \multirow[t]{3}{*}{ Pengalaman kerja } & Pearson Correlation & $.634^{* *}$ & 1 & $.566^{* * *}$ \\
\hline & Sig. (2-tailed) & .000 & & .000 \\
\hline & $\mathrm{N}$ & 66 & 66 & 66 \\
\hline \multirow[t]{3}{*}{ Disiplin kerja } & Pearson Correlation & $.471^{* *}$ & $.566^{* *}$ & 1 \\
\hline & Sig. (2-tailed) & .000 & .000 & \\
\hline & $\mathrm{N}$ & 66 & 66 & 66 \\
\hline
\end{tabular}

**. Correlation is significant at the 0.01 level (2-tailed).

Tabel 10 diatas, menyatakan korelasi yang terjadi antara variabel eksogen, sebagai bukti adanya kausalitas antar variable budaya, pengalaman dan disiplin kerja.

Dengan pendekatan analisis jalur, yakni kombinasi regresi variabel bebas terhadap variabel tak bebas (Kinerja) dan adanya hubungan kausalitas antar variabel bebas $\left(\mathrm{r}_{\mathrm{xi}, \mathrm{xj}}\right)$, dinyatakan dalam gambar 1 berikut:

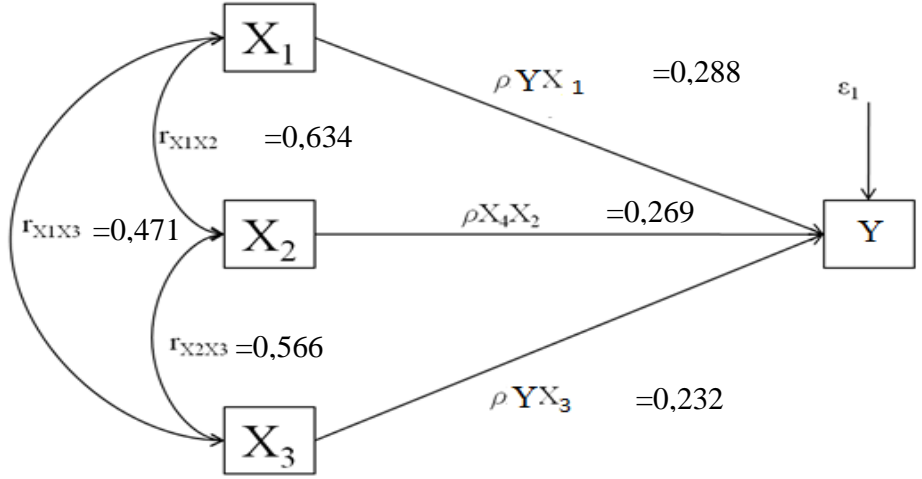

Keterangan :

$\mathrm{Y}=$ Kinerja pegawai

$\mathrm{X} 1=$ Budaya kerja

$\mathrm{X} 2=$ Pengalaman kerja

$\mathrm{X} 3=$ Disiplin kerja

Gambar 1 Diagram Jalur Penelitian

\section{e. Hasil Analisis Pengaruh variabel dan Pembahasan}

\section{(1).Pengaruh Budaya kerja terhadap Kinerja pegawai}

\section{Pengaruh langsung:}

Besarnya pengaruh langsung budaya kerja terhadap Kinerja pegawai, dinyatakan dengan besaran koefisien jalur $\left(\rho_{\mathrm{yx} 1}=0,288\right)$, Sehingga besarnya pengaruh langsung yakni: $(0,288)^{2} \mathrm{x} 100 \%=8,29 \%$.

\section{Pengaruh Tidak langsung}

Besarnya pengaruh tidak langsung budaya kerja terhadap Kinerja pegawai kantor kecamatan Peusangan, terkait dengan variabel eksogen lainnya, dihitung berikut ini:

- Pengaruh Budaya dan pengalaman terhadap Kinerja, adalah $(0,288)(0,634)(0,269) \times 100 \%=4,91 \%$

- Pengaruh Budaya dan disiplin terhadap Kinerja, adalah $(0,288)(0,471)(0,232) \times 100 \%=3,15 \%$

\section{Pengaruh Total Budaya kerja:}

Berdasarkan hal diatas, maka dapat dihitung besarnya pengaruh total yakni: $8,29 \%+4,91 \%+3,15 \%$, diperoleh sebesar $16,35 \%$. 


\section{(2).Pengaruh Pengalaman kerja terhadap Kinerja pegawai}

\section{Pengaruh langsung:}

Besarnya pengaruh langsung pengalaman kerja terhadap Kinerja pegawai, dengan $\rho_{\mathrm{yx} 2}=0,269$, Sehingga besar pengaruhnya adalah: $(0,269)^{2} \times 100 \%=7,24 \%$.

\section{Pengaruh Tidak langsung}

Besarnya pengaruh tidak langsung pengalaman kerja terhadap Kinerja pegawai di hitung masingmasing berikut ini:

- Pengaruh Pengalaman kerja dan Budaya terhadap Kinerja, adalah $(0,269)(0,634)(0,288) \times 100 \%=4,91 \%$

- Pengaruh Pengalaman kerja dan disiplin terhadap Kinerja adalah $(0,269)(0,566)(0,232)$ x $100 \%=3,53 \%$

Pengaruh Total Pengalaman kerja:

Berdasarkan hal diatas, maka total pengaruh variabel pengalaman kerja, yakni: 7,24\% +4,91\%+ $3,53 \%$, diperoleh sebesar $15,68 \%$.

\section{(3).Pengaruh Disiplin kerja terhadap Kinerja pegawai}

\section{Pengaruh langsung:}

Besarnya pengaruh langsung Disiplin kerja terhadap Kinerja pegawai, dengan $\rho_{\mathrm{y} \times 3}=0,232$, adalah: $(0,232)^{2} \times 100 \%=5,38 \%$.

\section{Pengaruh Tidak langsung}

Pengaruh tidak langsung Disiplin kerja terhadap Kinerja pegawai kantor kecamatan Peusangan, terkait dengan variabel eksogen lainnya di hitung masing-masing berikut ini:

- Pengaruh Disiplin kerja dan Budaya terhadap Kinerja adalah $(0,232)(0,471)(0,288) \times 100 \%=4,15 \%$

- Pengaruh Disiplin kerja dan pengalaman terhadap Kinerja adalah $(0,232)(0,566)(0,269) \times 100 \%=3,53 \%$.

\section{Pengaruh Total Disiplin kerja:}

Berdasarkan hal diatas, total pengaruh disiplin kerja pegawai terhadap Kinerja pegawai kantor Kecamatan Peusangan Kabupaten Bireuen, yakni: 5,38\% + 4,15\% + 3,53\%, diperoleh sebesar 12,06\%.

\section{(4).Analisis Pengaruh Budaya kerja, Pengalaman dan Disiplin terhadap Kinerja Pegawai}

Berdasarkan pengujian model jalur di atas maka dapat dituliskan persamaan untuk model jalur adalah sebagai berikut: $\quad Y=0,288 X_{1}+0,269 X_{2}+0,232 X_{3}$

( $\mathrm{Y}=$ Kinerja, $\mathrm{X}_{1}=$ Budaya kerja, $\mathrm{X}_{2}=$ Penaglaman kerja, $\mathrm{X}_{3}=$ Disiplin kerja)

Maka dari persamaan tersebut dapat dijelaskan bahwa dengan menerapkan Budaya kerja yang baik akan berdampak positif terhadap kinerja pegawai. Setiap kenaikan 10\% dari tingkat budaya kerja, maka secara rata-rata akan meningkatkan kinerja pegawai sebesar 2,88 persen.

Pengalaman kerja yang dimiliki para pegawai berdampak positif terhadap kinerja pegawai. Dan setiap adanya penambahan pengalaman kerja sebesar 10\%, akan meningkatkan kinerja pegawai rerata sebesar $2,69 \%$.

Demikian pula faktor disiplin kerja, juga berdampak positif pada kinerja pegawai. Dengan rata-rata peningkatan disiplin kerja 10\%, dengan sendirinya akan meningkat kinerja pegawai rata-rata $2,32 \%$.

Disamping model jalur diatas yang menujukkan adanya hubungan dan pengaruh, baik secara parsial maupun simultan, juga dapat ditinjau dari ukuran statistik lain, yakni nilai koefisien korelasi dan koefisien determinasi dalam model jalur yang dikembangkan. Hasil analisis koefisien korelasi dan determinasi variabel eksogen dengan variabel endogen didapatkan berikut:

Tabel 11. Koefisien Korelasi Simultan

\begin{tabular}{|c|c|c|c|c|}
\hline Model & R & R Square & Adjusted R Square & Std. Error of the Estimate \\
\hline Jalur & 0.663 & 0.440 & 0.413 & 2.32346 \\
\hline
\end{tabular}

Hasil analisis koefisien korelasi antara budaya kerja, pengalaman kerja dan disiplin kerja pegawai terhadap kinerja pegawai kantor Kecamatan Peusangan Kabupaten Bireuen diperoleh $R$ sebesar 0,663 menjelaskan hubungannya linier dan cukup tinggi, dengan derajat hubungannya sebesar 0,663 . Nilai koefisien determinasi sebesar 0,440 menjelaskan bahwa kontribusi faktor budaya kerja, pengalaman kerja dan disiplin kerja pegawai terhadap Kinerja pegawai kantor Kecamatan Peusangan Kabupaten 
Bireuen sebesar 44\%. Sementara sisanya dari peran variabel yang tidak diteliti sebesar $60 \%$, seperti faktor kompensasi, iklim organisasi, fasilitas kerja, Diklat, Kepemimpinan, dan lain-lain.

\section{Simpulan (Conclusion)}

\section{1). Analisis Kajian Deskriptif}

Budaya kerja yang terjadi pada kantor Kecamatan Peusangan Kabupaten Bireuen, baik dari aspek profesionalisme, disiplin, kerjasama, dan kejujuran, masuk kategori baik mencapai 77,23\%, walaupun belum optimal dalam mendukung kinerja pegawai. Pengalaman kerja pegawai di kantor Kecamatan Peusangan Kabupaten Bireuen baru mencapai 70,39\%, belum maksimal. Hal ini dinilai dari aspek pengalaman dalam menyelesaikan pekerjaan, sikap profesional, melaksanakan tugas sesuai prosedur, meminimalkan kesalahan yang terjadi dalam pekerjaan. Dan disiplin kerja pegawai, berkaitan dengan kehadiran bekerja, mampu melaksanakan beban kerja dan kerjasama, dan perinsip penegakan disiplin di kantor, belum maksimal, baru mencapai $75,39 \%$.

\section{2). Analisis Kajian Verifikatif}

a. Hasil analisis statistik faktor Budaya kerja berpengaruh terhadap Kinerja pegawai kantor kecamatan Peusangan Kabupaten Bireuen, dengan besar pengaruhnya 16,35\%

b. Juga aspek pengalaman kerja berpengaruh terhadap terhadap Kinerja pegawai kantor kecamatan Peusangan Kabupaten Bireuen, dengan besar pengaruhnyan15,68\%.

c. Dan terdapat pengaruh secara signifikan disiplin kerja terhadap Kinerja pegawai kantor kecamatan Peusangan Kabupaten Bireuen sebesar 12,06\%.

d. Dan berdasarkan Nilai koefisien determinasi menyatakan kontribusi faktor budaya kerja, pengalaman kerja dan disiplin kerja pegawai terhadap Kinerja pegawai kantor Kecamatan Peusangan Kabupaten Bireuen sebesar $44 \%$. Sementara sisanya dari peran variabel yang tidak diteliti sebesar $60 \%$, seperti kompensasi, iklim organisasi, fasilitas kerja, Diklat, Kepemimpinan, dan lain-lain.

\section{DAFTAR PUSTAKA (References)}

1) Asyrori. 2014, Hubungan Budaya Kerja dengan Kinerja Pegawai di Kantor Kecamatan Sambutan Kota Samarinda

2) Ghozali, Imam. 2011, Aplikasi Analisis Multivariate Dengan Program SPSS, Badan Penerbit Universitas Diponegoro, Semarang.

3) Hasibuan, Malayu. 2012. Manajemen Sumber Daya Manusia. Edisi Revisi. Jakarta: PT Bumi Aksara

4) Leiden, Robert. 2001, Managing Individual Performance In Works Groups. Journal Human Resources Management Vol 40.

5) Mangkunegara. 2005, Manajemen Sumber Daya Perusahaan. PT . Remaja. Rosdakarya. Bandung

6) Moeheriono. 2012, Pengukuran Kinerja Berbasis Kompetensi. Jakarta: Raja. Grafindo Persada

7) Prasetya. 2001, Evaluasi Proses Belajar Mengajar, (Jakarta: PAU-PAI,. Universitas Terbuka).

8) Riduwan. 2010. Skala Pengukuran Variabel-variabel Penelitian. Bandung: Alfabeta

9) Robbins dan Timothy. 2008, Perilaku Organisasi Edisi ke-12,. Jakarta: Salemba Empat.

10) Sedarmayanti. 2014, Sumber Daya Manusia dan Produktivitas Kerja. Jakarta: Mandar Maju.

11) Sutarno N.S. 2006. Manajemen Perpustakaan. Jakarta. CV Sagung

12) Sudjana, 2005. Metoda Statistika. Bandung: Tarsito

13) Wanceslaus Bili, dkk. 2018, Pengaruh Pengalaman Kerja Terhadap Kinerja Pegawai di Kantor Kecamatan Laham Kabupaten Mahakam Ulu. 